\title{
Zdrowy nos pacjenta sprzymierzeńcem specjalisty chorób płuc
}

\section{A healthy nose of patient as an ally of the lung specialist}

\author{
Piotr Rapiejko \\ Klinika Otolaryngologii i Onkologii Laryngologicznej z Klinicznym Oddziałem \\ Chirurgii Czaszkowo-Szczękowo-Twarzowej, Wojskowy Instytut Medyczny w Warszawie \\ Kierownik Kliniki: prof. dr hab. n. med. Dariusz Jurkiewicz
}

\begin{abstract}
Streszczenie:
Nos stanowi począłkowy fragment górnego odcinka dróg oddechowych. Jego podstawową funkcją jest pośredniczenie w wymianie gazowej, ale również zabezpieczanie dróg oddechowych przed wpływem zmiennych, zewnętrznych warunków atmosferycznych, substancji fizycznych i chemicznych zawartych we wdychanym powietrzu. Upośledzenie drożności nosa w przebiegu jego schorzeń, takich jak alergiczny nieżyt nosa czy rhinosinusitis, wpływa niekorzystnie na funkcje dolnych dróg oddechowych. Dwadzieścia lat po opublikowaniu pierwszego dokumentu Allergic Rhinitis at its Impact to Asthma (ARIA) idea zjednoczonych dróg oddechowych jest wciąż aktualna. Funkcją (lub dysfunkcją nosa) warto się zainteresować nie tylko u chorych z trudnymi do kontroli objawami schorzeń dolnych dróg oddechowych.

\section{Abstract:}

The nose is the initial part of the upper airway. Its primary function is to mediate gas exchange, but it also protects the respiratory tract from the effects of varying external atmospheric conditions as well as physical and chemical substances contained in the inhaled air. Impaired nasal patency in the course of nasal diseases such as allergic rhinitis or rhinosinusitis adversely affects the function of the lower respiratory tract. Twenty years after the first ARIA (Allergic Rhinitis at its Impact to Asthma) document was published, the idea of a unified airway is still relevant today. Nasal function (or dysfunction) is of interest not only in patients with difficult to control symptoms of lower respiratory tract diseases.
\end{abstract}

Słowa kluczowe: nos, funkcje nosa, ochrona dróg oddechowych Key words: nose, nasal function, protect the respiratory tract

\section{Wstęp}

Jeśli w codziennej praktyce - pomimo wydawałoby się optymalnego leczenia chorób dolnych dróg oddechowych - nie uzyskujemy zadowalającej kontroli objawów chorobowych, może warto poszukać przyczyny niepowodzeń w innych częściach dróg oddechowych. Może to wina nosa?

Znaczenie nosa dla prawidłowego funkcjonowania dróg oddechowych można rozważyć w trzech głównych obszarach:

1. Upośledzenie drożności nosa, a w konsekwencji zmiana toru oddychania $\mathrm{z}$ nosowego na ustny będą miały niekorzystny wpływ na dolne drogi oddechowe (brak oczyszczenia, nawilżenia i ogrzania wdychanego powietrza). Najczęstsze przyczyny to: skrzywienie przegrody nosa, polipy nosa (przewlekłe zapalenie błony śluzowej nosa i zatok przynosowych z polipami nosa), obrzęk i/lub przerost małżowin nosowych dolnych w przebiegu przewlekłego zapalenia błony śluzowej nosa i zatok przynosowych lub przewlekłego alergicznego nieżytu nosa.

2. Współwystępowanie chorób nosa i zatok przynosowych ze schorzeniami dolnych dróg oddechowych. Symptomy nieleczonych lub nieprawidłowo leczonych chorób nosa i zatok (np. gęsta wydzielina ściekająca po tylnej ścianie gardła) mogą nasilać objawy ze strony pozostałych struktur układu od- 
dechowego (np. kaszel). Najczęstsze przyczyny to przewlekłe zapalenie błony śluzowej nosa i zatok przynosowych z polipami i bez polipów nosa oraz alergiczny nieżyt nosa (ANN).

3. Choroby górnych i dolnych dróg oddechowych mają często wspólny patomechanizm; takie same komórki i mediatory procesu zapalnego, te same alergeny wywołują proces zapalny. W aspekcie zmian zapalnych jest to jedna choroba dróg oddechowych o różnej lokalizacji. Nos stanowi integralną część dróg oddechowych zgodnie z koncepcją zjednoczonych dróg oddechowych.

\section{Nos - spojrzenie chorego}

Dla pacjenta nos to przede wszystkim element kosmetyczny twarzy, początek drogi oddechowej i droga dotarcia wrażeń węchowych. Nos może wiązać się również z patologią; katarem, kichaniem, świądem, blokadą nosa, urazami, krwawieniem. Symptomy chorobowe ze strony błony śluzowej nosa, takie jak: upośledzenie drożności, katar przedni i zanosowy, świąd i kichanie, prowadzą do znacznego dyskomfortu, ograniczają codzienną sprawność psychofizyczną, w znaczący sposób wpływają na pracę i naukę chorego. Jednak w chwili, gdy do objawów ze strony nosa dołączą się symptomy ze strony dolnych dróg oddechowych, a pacjent znajdzie się pod opieką specjalisty chorób płuc lub specjalisty chorób wewnętrznych, objawy nosowe schodzą na dalszy plan. W trakcie konsultacji chory często koncentruje się na symptomach ze strony dolnych dróg oddechowych i nawet nieświadomie pomija „banalne” objawy ze strony nosa. Tym samym specjalista chorób płuc, jeśli wprost nie zapyta pacjenta o symptomy ze strony nosa, nie będzie miał pełnego obrazu klinicznego. Dołączenie się objawów chorobowych ze strony dolnych dróg oddechowych u chorego z ANN i rozpoczęcie stosowania leków ukierunkowanych na dolne drogi oddechowe często łączy się z przerwaniem dotychczasowej terapii donosowej. Nierzadko pacjenci uważają, że ich choroba nosa (ANN) przeszła na dolne drogi oddechowe. Zwykle nie oznacza to jednak przesunięcia procesu chorobowego $\mathrm{z}$ górnych na dolne drogi oddechowe, ale objęcie procesem chorobowym dodatkowo dolnych dróg oddechowych. Procesy zapalenia alergicznego (w przypadku ANN) nadal się toczą w obrębie błony śluzowej nosa i zatok przynosowych, tylko chory koncentruje się w większym stopniu na poważniejszych symptomach ze strony oskrzeli i płuc, zaniedbując tym samym leczenie błony śluzowej nosa i zatok przynosowych.

\section{Funkcje nosa}

W czasie wdechu zasadniczy strumień powietrza przechodzi od nozdrzy przednich do tylnych pomiędzy małżowiną nosową dolną a środkową. W trakcie wydechu powietrze przemieszcza się w odwrotnym kierunku w większym stopniu w niższych partiach jamy nosa. Turbulentny przepływ powietrza, cechujący się zawirowaniami, jest charakterystyczny dla szczytowej fazy wdechu i przyczynia się do zwiększenia kontaktu masy powietrza z powierzchnią błony śluzowej [1].

Funkcje nosa:

- początek drogi oddechowej (fragment górnych dróg oddechowych)

- funkcja nawilżania powietrza wdychanego

- funkcja ogrzewania powietrza wydychanego

- funkcja oczyszczania powietrza wydychanego

- miejsce reakcji immunologicznej

- narząd węchu

- funkcja rezonacyjna

- funkcja kosmetyczna (ryc. 1).

Rycina 1. Funkcje nosa.

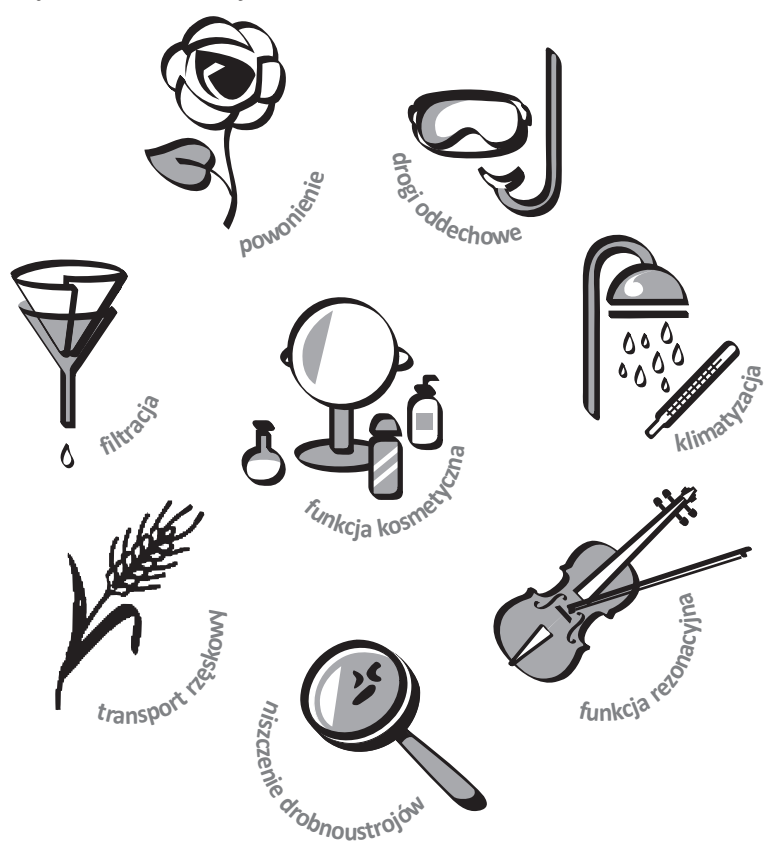

Upośledzenie drożności nosa (niezależnie od pierwotnej przyczyny) zaburza wszystkie funkcje nosa, co w konsekwencji wpływa na funkcjonowanie zarówno górnych, jak i dolnych dróg oddechowych.

Doskonałym przykładem ochronnego wpływu nosa na dolne drogi oddechowe jest nadreaktywność oskrzeli. Nadreaktywność oskrzeli to stan, w którym oskrzela chorego kurczą się pod wpływem bodźców zewnętrznych obojętnych dla osób zdrowych, tj. niewywołujących u nich skurczu oskrzeli [2]. Podstawowym 
symptomem nadaktywności oskrzeli zwykle jest skurcz oskrzeli, klinicznie objawiający się świstami lub suchym kaszlem [2]. Objawy te, pomimo że są przewlekłe, występują w pewnych, zwykle typowych sytuacjach, takich jak: wysiłek fizyczny, ekspozycja na suche lub zimne powietrze czy na zmiany temperatury otoczenia, ekspozycja na zanieczyszczenia powietrza, ekspozycja u osób uczulonych na podprogowe dawki alergenów, w tym alergenów zawodowych, ekspozycja na dym tytoniowy, gazy, mgły itp. [3]. Z ww. czynników (sytuacji) wywołujących symptomy nadwrażliwości oskrzeli jedynie wysiłek fizyczny jest niezależny od nosa. Wszystkie pozostałe czynniki mogłyby być zniwelowane lub przynajmniej znacząco zredukowane w przypadku prawidłowego toru oddychania (przez nos) oraz prawidłowego funkcjonowania błony śluzowej nosa.

\section{Najczęstsze schorzenia upośledzające drożność nosa i funkcje błony śluzowej nosa}

\section{Zmiany anatomiczne}

Skrzywienie przegrody nosa (J34.2)

Diagnostyka obejmuje badanie podmiotowe (brak poprawy drożności nosa po $\alpha$-mimetykach), badanie rynoskopowe/endoskopia lub fiberoskopia jam nosa, uzupełnione w wybranych przypadkach o tomografię nosa i zatok przynosowych.

Leczenie: chirurgiczne - operacja korekcyjna przegrody nosa. Terapia przywraca fizjologiczny układ struktur anatomicznych w obrębie jam nosa, umożliwiając również prawidłowe leczenie błony śluzowej nosa, jeśli jest ono niezbędne (u chorych ze współistniejącym ANN i przewlekłym zapaleniem zatok przy- nosowych [PZZP] lub przewlekłym zapaleniem zatok przynosowych z polipami nosa [PZZPzPN]).

\section{Alergiczny nieżyt nosa (J30)}

Diagnostyka obejmuje badanie podmiotowe (charakterystyczne symptomy występujące po kontakcie z alergenami powietrznopochodnymi, wykres objawów klinicznych pokrywający się z wykresem stężenia alergenu, np. pyłku roślin), badanie przedmiotowe, badania dodatkowe: testy skórne $\mathrm{z}$ alergenami, poziom sIgE w surowicy krwi, donosowe testy prowokacyjne $\mathrm{z}$ alergenem [4].

Leczenie (ryc. 2): większość, jeśli nie wszystkie powikłania ANN są związane z jednym, najważniejszym objawem ANN - upośledzeniem drożności nosa. Rolą specjalisty chorób płuc jest uświadomienie pacjentowi $\mathrm{z}$ ANN roli nosa $\mathrm{w}$ procesie oddychania, nawilżania, oczyszczania powietrza i ochrony dolnych dróg oddechowych przed niekorzystnym wpływem zewnętrznych czynników fizykochemicznych na stan błony śluzowej dolnych dróg oddechowych. Chory na ANN powinien mieć świadomość mechanizmów działania poszczególnych grup leków stosowanych w ANN i szczególnej roli, jaką w tym leczeniu odgrywają do glikokortykosteroidy donosowe (dnGKS), które jako jedyne (poza $\alpha$-mimetykami) wpływają na drożność nosa. Może warto u pacjenta ze współwystępowaniem chorób w obrębie górnych i dolnych dróg oddechowych dokonać przeglądu lekowego i upewnić się, że podstawą terapii ANN u takiego chorego jest dnGKS. U pacjentów z łagodnymi objawami ANN (VAS 0-5 pkt) możemy stosować dowolny lek pierwszego rzutu (ryc. 2). Jednak w przypadku zaburzeń drożności nosa

Rycina 2. Schemat leczenia alergicznego nieżytu nosa (na podstawie [4]).

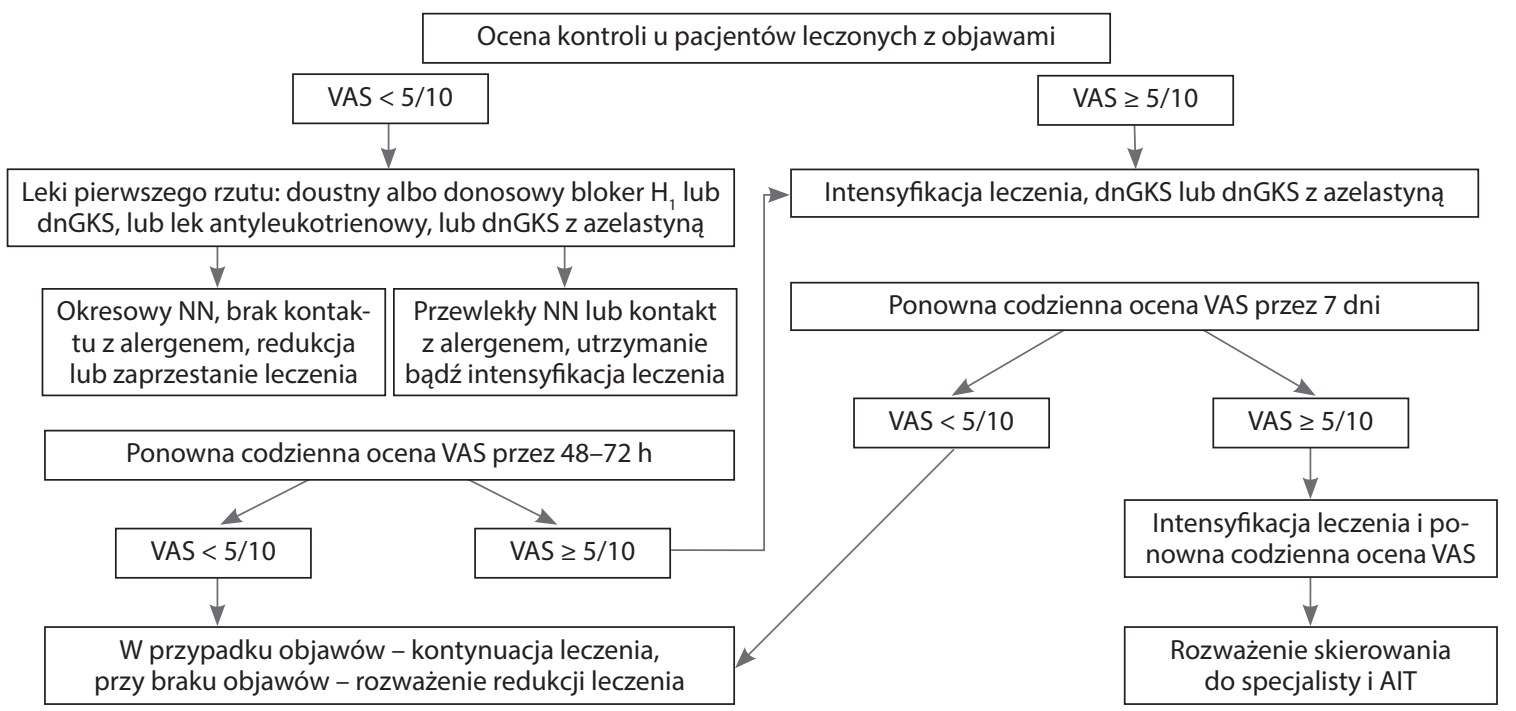

AIT (allergen-specific immunotherapy) - alergenowa immunoterapia swoista; dnGKS - glikokortykosteroid donosowy; VAS (visual analogue scale) - wizualna skala analogowa. 
i/lub schorzeń dolnych dróg oddechowych większą korzyść chory odniesie ze stosowania dnGKS (co oczywiście nie wyklucza dodatkowo przyjmowania leków przeciwhistaminowych).

Glikokortykosteroidy stosowane na błonę śluzową nosa wykazują silne działanie przeciwzapalne, dzięki czemu umożliwiają skuteczną redukcję praktycznie wszystkich symptomów ANN. Efekt kliniczny związany z wpływem na naczynia krwionośne błony śluzowej małżowin nosowych można zaobserwować już w 1. godzinie po zastosowaniu dnGSK, jednak pełen efekt kliniczny związany $\mathrm{z}$ wielokierunkowym działaniem przeciwzapalnym (osiąganym poprzez pobudzanie i hamowanie ekspresji genów) jest widoczny zwykle po kilku dniach stosowania. Bezpieczeństwo nowoczesnych dnGKS, takich jak: furoinian mometazonu, propionian mometazonu i furoinian flutykazonu, zostało udowodnione $\mathrm{w}$ bardzo wielu badaniach $[5,6]$.

Przewlekle zapalenie zatok przynosowych bez polipów nosa (J32) i z polipami nosa (J33)

Diagnostyka obejmuje badanie podmiotowe, badanie przedmiotowe ( $w$ tym endoskopia nosa), badania dodatkowe: tomografia nosa i zatok przynosowych (nie jest wymagana do ustalenia rozpoznania). Do ustalenia rozpoznania wystarczające jest badanie podmiotowe i przedmiotowe.

Zapalenie zatok przynosowych u osób dorosłych charakteryzuje się:

- co najmniej dwoma objawami, z których jednym powinna być:

- blokada nosa/obrzęk/upośledzenie drożności nosa albo

- wydzielina z nosa (katar przedni/tylny)

oraz

- \pm ból/uczucie rozpierania twarzy

- \pm zaburzenia węchu

i/lub

- stwierdzeniem w badaniu endoskopowym:

- polipów nosa i/lub

- wydzieliny śluzowo-ropnej, głównie w przewodzie nosowym środkowym, i/lub

- obrzęku błony śluzowej, zwłaszcza w przewodzie nosowym środkowym

i/lub

- zmianami w tomografii komputerowej:

- zmianami błony śluzowej w obrębie kompleksu ujściowo-przewodowego i/lub w zatokach.
Definicja zapalenia zatok u dzieci jest praktycznie taka sama jak u osób dorosłych, z tą różnicą, że w definicji nie występują zaburzenia węchu, lecz kaszel.

Leczenie (ryc. 3, 4): terapia PZZP i PZZPzPN opiera się na leczeniu przeciwzapalnym $\mathrm{z}$ zastosowaniem dnGKS oraz płukaniu jam nosa roztworami $0,9 \% \mathrm{NaCl}$ [7-9]. Steroidoterapia donosowa w leczeniu przewlekłego zapalenia zatok przynosowych ma skuteczność potwierdzoną licznymi badaniami, jest bezpieczna, zmniejsza objawy związane $\mathrm{z}$ chorobą oraz oddziałuje na poprawę jakości życia. Wpływ na redukcję objawów jest większy w przypadku zapalenia zatok przynosowych z polipami niż bez polipów. Wykazano, że steroidoterapia donosowa zmniejsza polipy nosa oraz sprzyja zapobieganiu ich nawrotom po endoskopowych operacjach zatok $[7,9]$.

\section{Koncepcja jedności dróg oddechowych}

Budowa błony śluzowej nosa i oskrzeli jest podobna, jednak w patogenezie objawów klinicznych w nieżycie nosa większą rolę odgrywają naczynia krwionośne, a w astmie - mięśnie gładkie oskrzeli [10]. Terapia zapalenia błony śluzowej górnych i dolnych dróg oddechowych opiera się na tych samych lekach przeciwzapalnych.

Zgodnie z dokumentem Polskie Standardy Leczenia Nieżytów Nosa (PoSLeNN) [8], poza działaniami terapeutycznymi zawartymi $\mathrm{w}$ dokumentach rejestracyjnych, dnGKS można również stosować w:

- nieżytach nosa wywołanych nietolerancją niesteroidowych leków przeciwzapalnych

- zespole niealergicznego nieżytu nosa z eozynofilią (NARES, non-allergic rhinitis with eosinophilia syndrome)

- polekowym nieżycie nosa (RM, rhinitis medicamentosa), spowodowanym nadużywaniem miejscowych leków obkurczających błonę śluzową nosa

- przewlekłych zapaleniach zatok przynosowych bez polipów

- zespole kaszlu związanym z górnymi drogami oddechowymi (UACS, upper airways cough syndrome).

Również dokument pt. Standardy postępowania $w$ pozaszpitalnych zakażeniach uktadu oddechowego zaleca stosowanie dnGSK w powirusowym, ostrym zapaleniu zatok przynosowych u osób dorosłych [11]. 
Rycina 3. Leczenie przewlekłego zapalenia zatok przynosowych w gabinecie POZ (dla lekarza nielaryngologa) wedtug EPOS 2020 (na podstawie [9]).

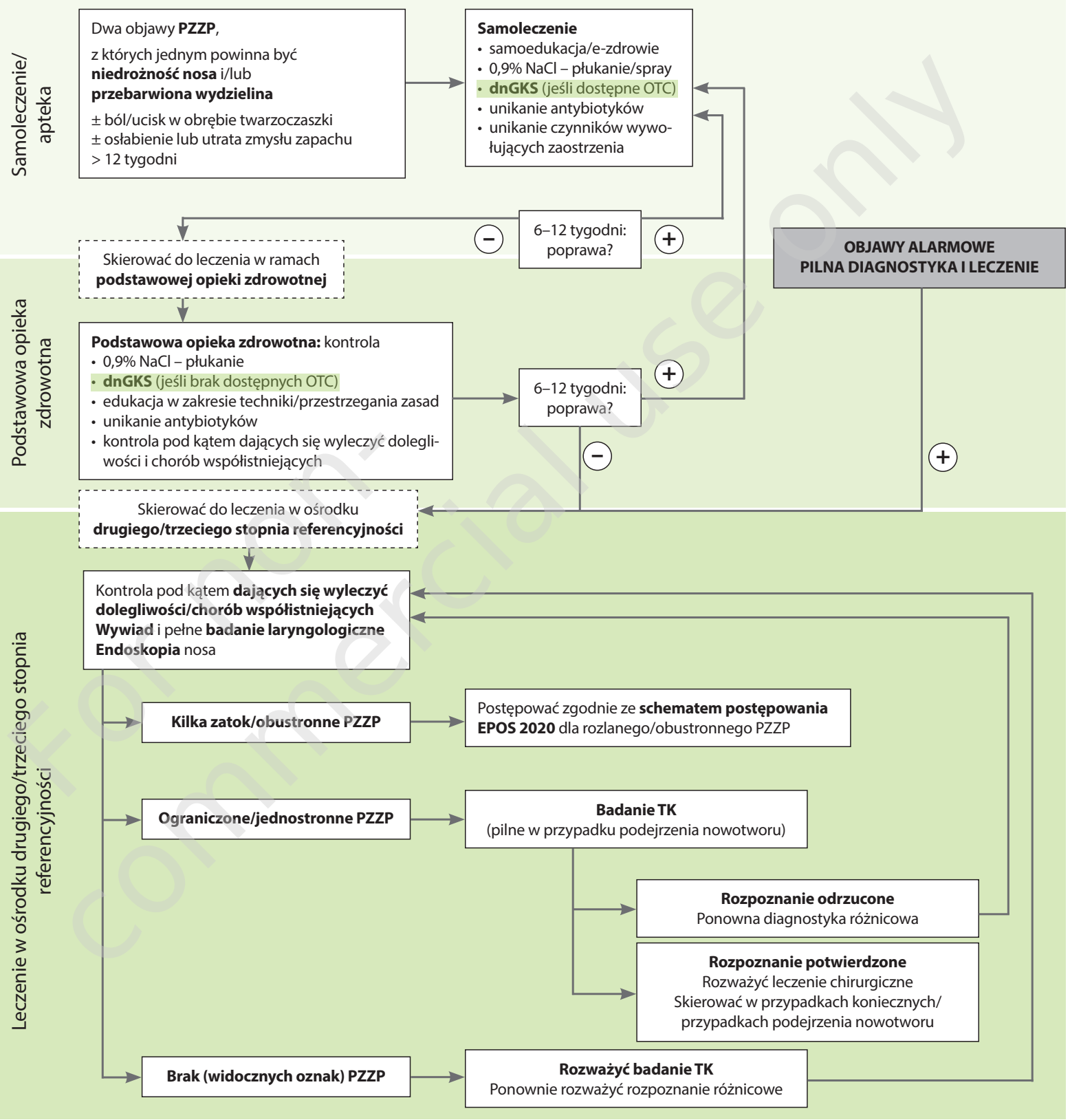

dnGKS - glikokortykosteroidy donosowe w aerozolu; OTC (over the counter) - leki dostępne bez recepty; PZZP - przewlekłe zapalenie błony śluzowej nosa i zatok przynosowych; TK - tomografia komputerowa.

Objawy alarmowe:

obrzęk/zaczerwienienie okolicy oczodołu, przemieszczenie gałki ocznej, podwójne widzenie, zaburzona ruchomość gałki ocznej, pogorszenie ostrości wzroku, silny ból głowy, obrzęk w okolicy czołowej, objawy posocznicy, objawy zapalenia opon mózgowych, objawy neurologiczne, jednostronne występowanie objawów, występowanie krwawień, występowanie strupów, kakosmia.

W 2001 r. powstał raport grupy roboczej ARIA, który kierując się zasadami medycyny opartej na faktach (EBM, evidence based medicine), stał się zbiorem wytycznych w leczeniu ANN. Dokument ARIA wyraźnie sprecyzował, że „u chorych na astmę należy przeprowadzić diagnostykę w kierunku ANN", a „u chorych na ANN należy przeprowadzić diagnostykę w kierunku astmy” oraz iż ,w celu osiągnięcia największej skuteczności terapii należy stosować skojarzone leczenie górnych i dolnych dróg oddechowych". 
Rycina 4. Leczenie przewlektego zapalenia zatok przynosowych o objawach nasilonych w gabinecie laryngologicznym wedlug EPOS 2020 (na podstawie [9]).

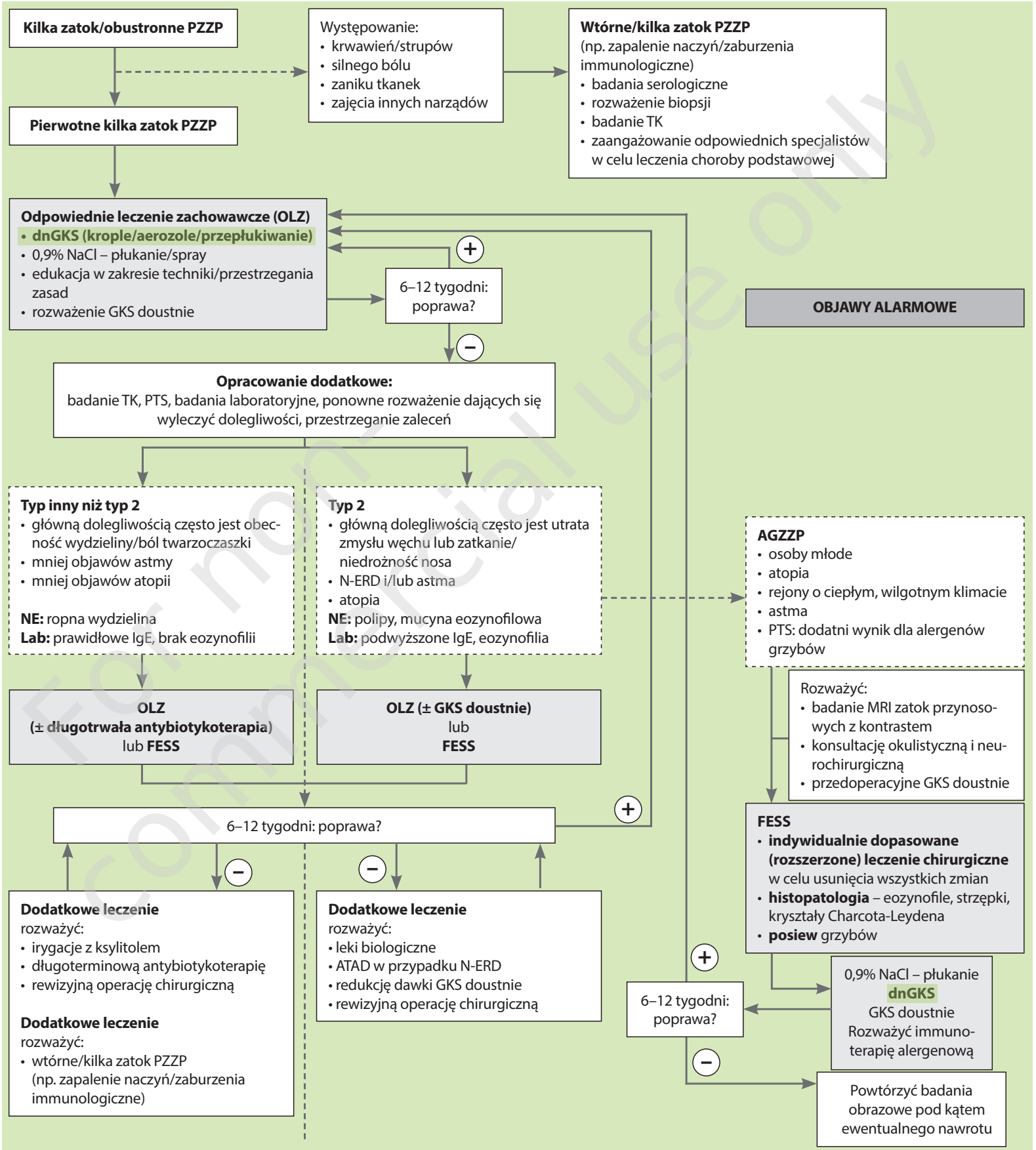

AGZZP - alergiczne grzybicze zapalenie zatok przynosowych; ATAD - leczenie aspiryna po desensytyzacji; dnGKS - glikokortykosteroidy donosowe; FESS - funkcjonalna endoskopowa chirurgia zatok przynosowych; MRI - obrazowanie metodą rezonansu magnetycznego; NE - endoskopia nosa i zatok; N-ERD - choroba dróg oddechowych zaostrzana przez niesteroidowe leki przeciwzapalne; PTS - punktowy test skórny z alergenami; PZZP - przewlekłe zapalenie błony śluzowej nosa i zatok przynosowych; TK - tomografia komputerowa.

Objawy alarmowe:

obrzęk/zaczerwienienie okolicy oczodołu, przemieszczenie gałki ocznej, podwójne widzenie, zaburzona ruchomość gałki ocznej, pogorszenie ostrości wzroku, silny ból głowy, obrzęk w okolicy czołowej, objawy posocznicy, objawy zapalenia opon mózgowych, objawy neurologiczne, jednostronne występowanie objawów, występowanie krwawień, występowanie strupów, kakosmia. 


\section{Podsumowanie}

Główny cel, jaki mi przyświecał w trakcie pisania tego artykułu, to próba przekonania Szanownych Czytelników do przyjaznego spojrzenia na nos i zatoki.

Każdy chory ze schorzeniami dolnych dróg oddechowych (nawet dobrze kontrolowanymi) powinien być diagnozowany w kierunku współwystępowania chorób nosa i zatok przynosowych oraz anomalii anatomicznych w obrębie jam nosa.

\section{Piśmiennictwo}

1. Jurkiewicz D, Rapiejko P. Fizjologia nosa i zatok przynosowych. In: Niemczyk K, Jurkiewicz D, Sktadzień J et al (ed). Otolaryngologia kliniczna. Vol. 2. Medipage, Warszawa 2015: 319-24.

2. Pawliczak R. Nadreaktywność oskrzeli w praktyce klinicznej. Terapia. 2021; 4: 66-72

3. Juusela M, Pallasaho P, Rönmark E et al. Dose-dependent association of smoking and bronchial hyperresponsiveness. Eur Respir J. 2013; 42(6): 1503-12.

4. Samoliński B, Krzych-Falta E, Piekarska B et al. 2019 ARIA - Care pathways for allergic rhinitis - Poland. Alergologia Polska - Polish Journal of Allergology. 2019; 6(4): 111-26. http://doi.org/10.5114/pja/2019.91214.

5. Ratner PH, Meltzer EO, Teper A. Mometasone furoate nasal spray is safe and effective for 1-year treatment of children with perennial allergic rhinitis. Int J Pediatr Otorhinolaryngol. 2009; 73(5): 651-7.

6. Arcimowicz M. Glikokortykosteroidy donosowe: fakty i mity. Alergoprofil. 2016; 12(3): 113-21.
7. Fokkens WJ, Lund VJ, Hopkins C et al. European Position Paper on Rhinosinusitis and Nasal Polyps, Rhinology. 2020; 58(suppl S29): 1-464. http://doi.org/10.4193/Rhin20.600.

8. Samoliński B, Arcimowicz M (ed). PoSLeNN. Alergologia Polska - Polish Journal of Allergology. 2012; S1: 1-167.

9. Rot P, Rapiejko P, Jurkiewicz D. Intranasal steroid therapyEPOS 2020. Otolaryngol Pol. 2020; 74(3): 41-9. http://doi. org/10.5604/01.3001.0014.2449.

10. Bosguet J, Cauwenberge PW, Khaltaev $N$ et al. Allergic rhinitis and its impact on asthma. J Allergy Clin Immunol. 2001; 108(5 suppl): S147-334. http://doi.org/10.1067/ mai.2001.118891.

11. Hryniewicz W, Albrecht P, Radzikowski A. Rekomendacje postępowania $w$ pozaszpitalnych zakażeniach układu oddechowego. Narodowy Instytut Leków, Warszawa 2017.

ORCID

P. Rapiejko - ID - http://orcid.org/0000-0003-3868-0294

Konflikt interesów/Conflict of interests:

Nie wystepuje.

Finansowanie/Financial support:

Nie występuje.

Etyka/Ethics:

Treści przedstawione w artykule są zgodne z zasadami Deklaracji Helsińskiej, dyrektywami EU oraz ujednoliconymi wymaganiami dla czasopism biomedycznych.

Copyright: (c) Medical Education sp. z 0.0. This is an Open Access article distributed under the terms of the Attribution-NonCommercial 4.0 International (CC BY-NC 4.0). License (htpps:/creativecommons.org/licenses/by-nc/4.0/), allowing third parties to copy and redistribute the material in any medium or format and to remix, transform, and build upon the material, provided the original work is properly cited and states its license.

\section{Adres do korespondencji}

\section{dr n. med. Piotr Rapiejko}

Klinika Otolaryngologii i Onkologii Laryngologicznej z Klinicznym Oddziałem Chirurgii Czaszkowo-Szczękowo-Twarzowej, Wojskowy Instytut Medyczny 04-141 Warszawa, ul. Szaserów 128 